\section{Et vellykket eksperiment}

Espen Stueland

Gjennom kjøttet: disseksjonen og kroppens kulturhistorie

777 s, ill. Oslo: Oktober, 2009. Pris NOK 499 ISBN 978-82-495-0281-3

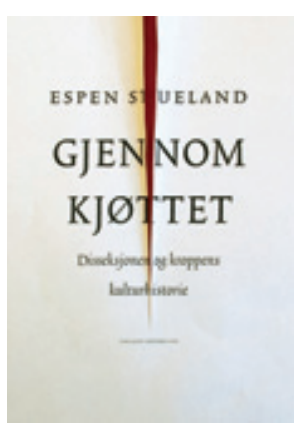

Selv om folkets tillit til legene er blitt svekket de seneste tiårene, er forventningen om at biomedisinen skal løse alle våre sosiale og medisinske problemer fremdeles sterk. Medisinske perspektiver på helse,

kropp, sykdom og lidelse dominerer fremdeles i små og store offentligheter. Fortsatt er det til sjuende og sist medisinen vi mener skal helbrede sykdom og lidelse og hindre for tidlig død. Men denne optimismen har som bivirkning at menneskekroppens ultimate skjørhet og skrøpelighet blir neglisjert. I vår vestlige verden fremstår døden som en fremmed, mystisk, skremmende hendelse, og en uventet sådan for de fleste andre enn de som tilbringer sin tilværelse på sykehjem. Vi forventer å leve lenge, å være friske mens vi lever, og at all medisinsk og kirurgisk behandling skal krones med suksess. For de fleste av oss blir disse forventningene også faktisk innfridd. Men de kommer med en pris: Døden og den døde kroppen er blitt skjøvet ut av vår hverdag. Det er paradoksalt, for mediene flommer over av parterte kropper i de mange rettsmedisinske kriminaldramaene og av kropper på operasjonsbordet i TV-serier som Grey's anatomy. Men i vår virkelige verden er døende og døde kropper gjemt bort, på sykehus og sykehjem, på hospice og på kirkegårder. Mange av oss går gjennom livet uten en eneste gang å ha sett en død kropp.

\section{Den døde kroppen}

Espen Stuelands bok Gjennom kjøttet: disseksjonen og kroppens kulturhistorie har nettopp den døde kroppen som tema. I løpet av de tettskrevne 770 sidene er det knapt en side ved den døde kroppen som ikke blir berørt. La det være sagt med en gang: Dette er en rik, lærd og svært god bok - den mest interessante sakprosautgivelsen jeg har lest på norsk på veldig lenge. Utgangspunktet er, som tittelen sier, svært materielt, konkret og håndfast: Det handler om kroppen som kjøtt, som åndløs materie. Den døde kroppen slik den foreligger på disseksjonsbordet, i poesien og bildekunsten, i dagens mange TV-serier, i politikken og i rettssalen, i tidligere tider og i dag. Espen Stueland tar oss med på en reise i tid og rom og til ulike tradisjoner, for å se hvordan dette kjøttet har fremstått til ulike tider, i ulike kulturer og i ulike miljøer. Disseksjonens og obduksjonens historie belyses ikke bare gjennom klassisk medisinhistorisk litteratur, men også gjennom filosofi, kunsthistorie, litteratur, religion, etikk og samtidens popkultur, bare for å nevne noe. Det er rett og slett et imponerende stykke tverrfaglig eksperiment.

Spørsmålet reiser seg nærmest umiddelbart: Hva slags bok er dette? Noe klassisk historieverk er det ikke - historikerne skriver sine fortellinger basert på kronologi, mens forfatteren her forakter kronologi. Han omtaler 1800-tallspoeten Baudelaire sammen med dagens TV-seriefigur $\mathrm{dr}$. House og renessansens anatom Vesalius. Noen kunsthistorie er det heller ikke, for kunstanalytiske perspektiver er ikke det sentrale, selv om de er der. Og det er slett ikke skjønnlitteratur. Espen Stueland er en prisbelønnet lyriker, romanforfatter og kritiker, men det er overraskende lite å spore av det poetiske og rike språket han ikler bøkene sine når han ikke skriver prosa.

Gjennom hele boken blir det tydelig hvor lite statisk kroppen er, og Stueland viser godt hvordan fortidens mennesker, inkludert leger, poeter og kunstnere tenkte helt annerledes om kroppen. Det er en helt annen kropp som fremkommer hos renessansepoetene enn hos dagens kroppsbesatte kunstnere, og døden får en helt annen form i Vesalius' anatomibok enn i Gunther van Hagens omdiskuterte kommersielle utstillinger av døde kropper. I en fantastisk passasje forteller Stueland sykehistorien til 1600-tallspoeten John Milton, i dag kjent som forfatteren av Paradise Lost. Både han selv og legene hans tolket hans tiltakende blindhet som resultatet av en tåke som hadde sitt utspring i fordøyelsesproblemer, og som steg opp fra magen og satte seg i blikket.

Men her er også fine refleksjoner over hvilket maktspill disse kroppene er blitt innlemmet i. På begynnelsen av 1800-tallet ble likene viktige for medisinsk vitenskap og praksis. Da begynte medisinerne systematisk å utforske patologiske forandringer i det døde legemet, og de fant nøkkelen til det levende i de døde kroppene. Problemet var mangelen på lik. Det ble kompensert ved bruk av kriminelle og fattige kropper, og de døde kroppene ble skamløst omtalt som kommersielle produkter i den medisinske litteraturen fra begynnelsen av 1800-tallet av. I The British Anatomy Act av 1832 făr legene lov til å dissekere de fattige kroppene som ikke er blitt gjort krav på av noen andre, og det blir tydelig at disseksjonen har både en moralsk og en juridisk side. Dette er for så vidt kjent fra tidligere medisinhistorisk litteratur (1), men Stuelands gjengivelse făr ny verdi ved at det knyttes til dagens problematiske organhandel i den tredje verden.

\section{En bok om livet}

Forakten for det kronologiske perspektivet gjør at forfatteren også har interessante blikk på samtiden. Før 1900-tallet var disseksjon omgitt av moralske forbud. Disseksjonen av kroppen brøt med forestillinger om døden som noe hellig, mystisk og uangripelig. På 1500-tallet oppfattet man disseksjon som en straff, en skjebne verre enn døden, selv om den skulle tjene en hensikt som lærestykke for medisinen. Når kriminelle ble dissekert,

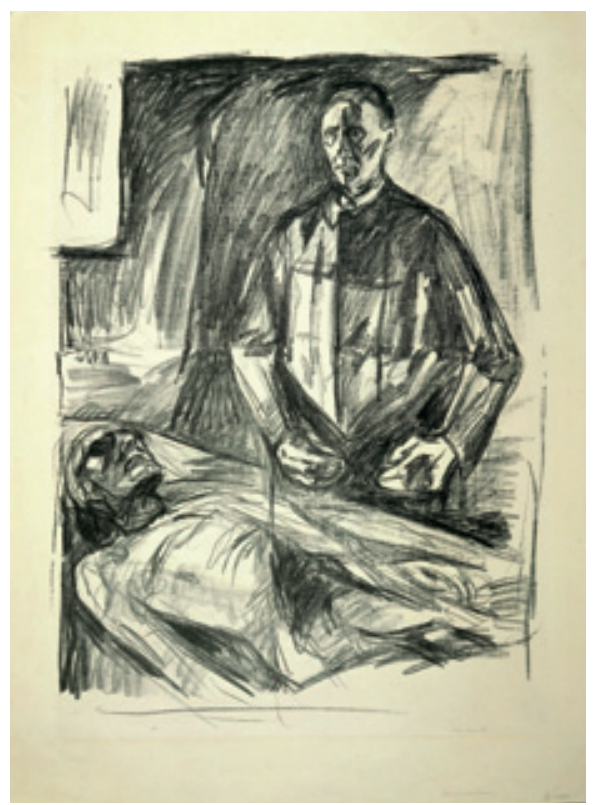

Edvard Munch (1863-1944) utførte flere portretter av anatomen Kristian Schreiner (1874-1957).

På ett av dem ligger Munch på disseksjonsbenken med Schreiner ved siden, klar til å starte undersøkelsen (1928-29). Litografi. Munch-museet. Copyright Munch-museet/Munch Ellingsen gruppen/BONO 2010 
ble det betraktet som en forlengelse av den lidelsen den dømte ble påført i levende live i fengselet. Disseksjonens løsrivelse av enkelte organer ble betraktet som et symbolsk uttrykk for samfunnsmessig uorden. Menneskekroppen ble i tidlig moderne tid ansett som et mikrokosmos, som gjenspeilte den store orden, makrokosmos. Makrokosmos var både Guds hellige orden og samfunnets orden. Det å ta fra hverandre mikrokosmos i sine enkelte deler kunne føre til at politikken og samfunnets orden ville bryte sammen (1). Stueland trekker folkelige og medisinske forestillinger om disseksjon helt opp til vår egen tid. I transplantasjonsloven, sist revidert i 2008, er et av argumentene fremdeles eierskap til egen kropp etter at sjelen har forduftet. Stueland bemerker at sentimentaliseringen av liket vokser med økende sekularisering. Det blir stadig vanskeligere å få samtykke fra pårørende til obduksjoner, og det er stadig mindre offentlig vilje til å påkoste obduksjoner, til patologenes store protester - og det $\mathrm{i}$ en tid da liket på obduksjonsbenken er blitt stadig vanligere på TV-skjermen.

Stueland trekker tidvis en del tvilsomme slutninger av materialet han presenterer, og han lar seg stedvis fascinere av medisinhistorisk materiale som med rette har fått kritikk for å være for spekulativt. I tillegg skulle man ofte ha ønsket seg en mer aktiv redaktør. Det blir litt mange løse tråder, litt mange spørsmål uten svar - har forfatteren fått helt frie tøyler fra sitt forlag her? Fine illustrasjoner, tykt og godt papir, og en murstein av en bok som jeg tviler på har solgt så mye at det har lønnet seg, til tross for at den fikk stor oppmerksomhet.

Samtidig: Det virker smålig å gjøre manglende redaksjonell inngripen til gjenstand for kritikk, all den tid det viktige er at forlaget faktisk har våget satse på denne utgivelsen, i en tid der vi ser færre og færre av slike stortstilt anlagte utgivelser. Det kan dessuten være at det var en riktig prioritering å la Stuelands fascinasjon for stoffet styre fremstillingen. Han har brettet ut et stort lerret av enormt fascinerende stoff, et stoff som gjør at vi forstår mer, ikke bare av vår historie, men kanskje først og fremst av vår samtid. Gjennom å vise de skiftende forestillingene om den døde kroppen blir det også tydelig at det ikke alltid har vært slik. Forestillingene om den døde kroppen virker så uunngåelige, naturlige og kulturelt nødvendige at det er viktig å få en påminnelse om at det har vært andre tider, andre steder, der den døde kroppen har fremstått som radikalt annerledes. Det gjør at det også åpner seg muligheter for å tenke annerledes om den i dag. Men Stueland leverer likevel ikke det tradisjonelle angrepet på den reduksjonistiske medisinen, tvert imot viser han hvordan det innenfor medisinen selv finnes mange måter å tenke om døden på, som det gjør for alle de kunstartene som er blitt inspirert av kroppen gjennom tidene. Det er selvsagt mulig å si at Stuelands bok er et symbol på vår tids besatthet av de døde kroppene slik den fremstår i alt fra samfunnsforskning til populærkultur. Men det er ikke populærkulturens glaserte og polerte døde kropp vi ser her, tvert imot er det en konkret og materiell kropp som vises frem i alle sine sjatteringer. Stueland beskriver også i noen fine passasjer sin egen motstand mot den døde kroppen, som han trosser ved å overvære en disseksjon på anatomisalen. I disse skildringene av en forfatter som kjemper med de ubehagelige sanseinntrykkene (lukt, lyd, syn) og sin egen motstand der han står og overværer obduksjonen, blir det tydelig at dette til sjuende og sist er en bok om livet. En svært interessant sådan.

\section{Anne Kveim Lie}

Institutt for helse og samfunn

Universitetet i Oslo

\section{Litteratur}

1. Richardson R. Death, dissection and the destitute. London/New York: Routledge, 1987: 84

2. Pouchelle MC. The body and surgery in the middle ages. Cambridge and Oxford: Polity Press, 1990.

\section{Disseksjon - en medisinsk overgangsrite}

John Harley Warner, James M. Edmonson Dissection

Photographs of a rite of passage in American medicine 1880-1930. 208 s, ill. New York, NY: Blast Books, 2009. Pris USD 50 ISBN 978-0-922233-34-2

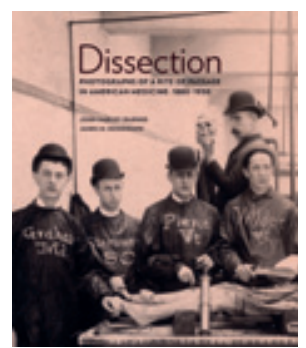

Disseksjonen har lenge vært et symbol på medisinens rene kunnskapstørst. I renessansen skal medisinske pionerer ha trosset et religiøst forbud og begynt jobben med å undersøke kroppens innside for å uteske dens hemmeligheter. Under den franske revolusjonen grunnla anatomen Xavier Bichat (1771-1802) «pariserskolen» på en doktrine om opplysning gjennom disseksjon: «Åpne noen lik og du vil jage vekk det mørket som observasjon alene ikke var i stand til å trenge gjennom.» Bichat trakk medisinstudentene inn i disseksjonsrommet, og slik ble disseksjonen en uomgjengelig del av den medisinske utdanningen. Her kom den til å spille en rolle ikke bare for kunnskapen om anatomi, men også for utformingen av en medisinsk identitet.

Den sterke veksten i medisinutdanningen på 1800-tallet skapte et stort marked for lik. Og markedsverdien på lik la til rette for en rekke tvilsomme avtaler mellom de som hadde tilgang, og de som hadde behov endog med drap for å skaffe til veie riktig ferske lik. Disseksjonen var innhyllet i et mistenksomhetens skjær og sto med ujevne mellomrom i brennpunktet for store skandaler. På den ene siden var den en potensielt skandaløs virksomhet, på den andre siden var den en naturlig del av utdanningen til et stadig økende antall leger.

I denne langvarige prosessen skjedde det også noe med offentligheten rundt disseksjonen. De anatomiske teatrene som ble bygd fra 1500-tallet, var bl.a. offentlige arenaer der folk kom for å tilfredsstille sin skuelyst. Medisinske professorer dissekerte og demonstrerte sitt håndlag med lik i spesialbygde anatomiske teatre for et vitebegjærlig publikum. Den berømte illustrasjonen som prydet forsiden på De humani corporis fabrica (1543) av Andreas Vesalius (1514-64), viser anatomen og forfatteren ved siden av et åpnet lik omgitt av en svært broket forsamling av studenter og skuelystne, inkludert et skjelett, en apekatt og noen kjeruber. Rembrandt og andre nederlandske 1600-tallsmalere brukte disseksjonen som kulisse for gruppemalerier av fremstående borgere. Renessansens disseksjoner var i mindre grad forskning enn demonstrasjoner. Disseksjonens historie er nylig grundig utforsket i Espen Stuelands vitale bok Gjennom kjøttet (1). Den må derfor i liten grad ha hatt en distingverende funksjon. 1800-tallets disseksjon på sin side, symbolisert ved Bichats dramatiske metafor, var en forskningsmetode, grunnsteinen i den patologiske anatomien, og tilskuerposisjonen ble strengt forbeholdt de medisinsk studerende. Disseksjonen var ikke lenger en virksomhet som gjorde det mulig å beskue et Guds under, men en forskningsmetode, og studentenes egne erfaringer med disseksjon under studiene gjorde det mulig for dem å gjøre personlige erfaringer med medisinen som vitenskap.

I en tid uten noen særlig klinisk trening var post mortem-disseksjonene studentenes eneste erfaring med «learning by doing». Disseksjonen ble en innvielsesrite for leger.

\section{Disseksjonsfotografiet}

Dette er den historiske bakgrunnen for de fotografiene som legges frem i Dissection. I boken dokumenterer man en paradoksal sjanger: Den rutinemessige avbildningen av en virksomhet som foregikk i selvpålagt hemmelighet. Fotografiene viser en virksomhet som var en integrert del av den medisinske selvforståelsen, og som i deler av den perioden de skriver seg fra, var ulovlig i enkelte amerikanske stater. Det oppsto naturlig en «hemmelighetens kultur» rundt disse disseksjonene, skriver John Harley Warner i det instruktive introduksjonsessayet. «Elever skal ikke avsløre hemmeligheter fra disseksjonsrommet», uttalte det medisinske fakultetet i Ohio i 1849. Og samtidig inviterte altså medi- 